\title{
The impact of invented spelling on phonemic awareness
}

\author{
Margarida Alves Martins*, Cristina Silva \\ Instituto Superior de Psicologia Aplicada (Higher Institute of Applied Psychology - I.S.P.A.), Rua Jardim do Tabaco, \\ 34, 1149-041 Lisboa, Portugal
}

\begin{abstract}
The objective of this study was to assess the impact of a training programme, designed to make preschool-age children's invented spelling evolve, on their phonemic awareness. The participants were 90 children who were divided into 3 experimental and 3 control groups based on the nature of their invented spelling. Children's phonemic skills were evaluated in a pre-test and a post-test. In between the experimental groups underwent the training program. The experimental groups achieved greater progress in the phonemic tests than the control groups. The training's impact on those tests differed depending on the level of the children's invented spelling.
\end{abstract}

(c) 2006 Elsevier Ltd. All rights reserved.

Keywords: Phonemic awareness; Invented spelling; Preschool children

\section{Introduction}

Ferreiro $(1984,1988)$ was one of the first researchers to study children's early ideas about written language.

Her work (1988) suggests that children's knowledge of written language evolves in a process that essentially takes place on three levels. Over the course of this evolutionary path children think about the nature of writing and build up conceptual hypotheses that reflect an active reconstruction of the logic of the units that are represented by written language. To begin with children's writing does not take linguistic segments into account and is organised on the basis of grapho-perceptive criteria, such as a minimum number of letters and the ways in which those letters vary when words are written down. Subsequently children evolve towards attempts to establish correspondences between oral and written units. They start by using syllables as their basis - often without yet mobilising conventional letters - then begin to establish qualitative correspondences with appropriate letters, and finally evolve to the point at which they understand the structure of alphabetic notation. With a few differences derived from the particular characteristics of each language and with variations in the names by which the authors in question designate the various phases of evolution, this evolutionary path has been identified for a wide range of languages, including French (Besse, 1996), Portuguese (Alves Martins, 1993), Italian (Pontecorvo \& Orsolini, 1996), Hebrew (Tolchinsky, 1995) and English (Sulzby, 1989).

In the light of the relative uniformity of this evolutional sequence, various authors began to think about the educational consequences of children's invented spelling prior to formal education. From the work of Read (1986)

\footnotetext{
* Corresponding author. Tel.: +351218 811 700; fax: +351218 860954.

E-mail address: mmartins@ispa.pt (M.A. Martins).
} 
onwards, Anglo-Saxon research sometimes saw invented writing as a mere indicator of phonological awareness (Mann, 1993) and included it in the huge mass of literature about the relationship between phonological awareness and learning to read. Over the last 30 years phonological awareness - that is to say, the ability to analyse the structure of the sounds in words - has been the object of wide-ranging debate. Despite the fact that the empiric relationship between phonological awareness and learning to read has been successively confirmed, discussion continues as to whether the former is a precondition for the latter (Goswami \& Bryant, 1990; Liberman \& Shankweiler, 1989; Mann, 1984), or a consequence of the alphabetisation process (Morais, Cary, Alegria, \& Bertelson, 1979). This argument also extends to the impact that phonological programs have on the prevention of learning difficulties. Bus, Marinus, and Ijzendoorn (1999) analysed the impact that 36 experimental phonological training studies had on learning to read and concluded that this type of intervention program significantly affects both the promotion of phonological awareness and - albeit to a lesser extent - reading skills. At the same time, when he looked at the methodological characteristics of this type of study, Troia (1999) confirmed the positive effect that phonological training has on phonemic synthesis and analysis. Having said this, he also questioned whether it had been unequivocally proven that such programs produce lasting effects and are ecologically valid. Although it is not this article's purpose to take the debate on this issue any further, aspects such as the variety and differing degrees of difficulty of the tasks that the various studies have used to assess phonological awareness, the fact that in this type of study children are dichotomously classified as readers or non-readers without conducting additional analyses of the extent of their knowledge about written language, and also the fact that the same studies have primarily employed reading measures, but rarely writing measures (Ferreiro, 2002; Vernon \& Ferreiro, 1999), are all factors that are not only important, but are very often neglected in the literature on phonological awareness.

These days, even the Anglo-Saxon literature has begun to emphasise the importance of invented writing in its own right, rather than just as an indicator of phonological awareness. Adams (1998) and Treiman (1998), for example, argue that children's invented spelling can be an instrument that facilitates the development of an awareness of the oral segments of words. Given the empirically tested relationship between phonological awareness and success at learning to read (Goswami \& Bryant, 1990; Perfetti, Beck, Bell, \& Hugues, 1987; Wagner \& Torgesen, 1987), this hypothesis that in functional contexts, engaging in invented spelling can promote the capacity to analyse words at the phoneme level, suggests the possibility that like phonological training programs, stimulating invented spelling could be an important pedagogical practise when it comes to preventing difficulties with learning to read.

Along the same lines Treiman (1998) considers that preschool-age children's invented spelling (e.g. BT for "beat") is a means of promoting phonemic awareness and modelling children's conceptions of phonemic entities; in this respect the quality of children's spelling is an excellent indicator of their phonological abilities and a good predictor of their subsequent success in the alphabetisation process. The value of invented spelling as a predictor of success at learning to read has indeed been confirmed by various studies (Mann, 1993; Richgels, 1995).

Treiman (1998) also considers that children's invented spelling may facilitate their acquisition of insights into the alphabetic structure of writing, inasmuch as they mobilise and apply activities involving metalinguistic reflection about speech as a function of their attempts to write words.

This position is also defended by Adams (1998), when she states that: "the evidence that invented spelling activity simultaneously develops phonemic awareness and promotes understanding of the alphabetic principle is extremely promising, especially in view of the difficulty with which children are found to acquire these insights through other methods of teaching." (p. 387).

Ouzoulias (2001) takes this point of view a step further when he argues that the possibility that preschool-age children will develop phonemic awareness is derived from what they know about written language. The underlying idea is that thanks to their invented spelling activities, children begin to discern more abstract phonological units than syllables and that consequently their first phonemic analyses result from a combination of the understanding that writing codifies language and the use of conventional letters at a syllabic level.

This standpoint becomes more consistent thanks to the fact that grasping the phonological patterns which characterise letter names by learning the alphabet - a requirement if a child is to mobilise letters with a conventional sound value in his/her invented spelling - is a factor that facilitates the development of explicit forms of phonemic awareness (Treiman, Tincoff, \& Richmond-Welty, 1997). Stahl and Murray (1994) suggest the same idea - in one study they found that all the subjects who were able to manipulate intra-syllabic units (units of the onset/rime type that are smaller than syllables) were familiar with a large number of letters, and concluded that familiarity with letters is an indispensable precondition for the development of phonological awareness. They deduced from this that 
when letters are mobilised in invented spelling contexts, they can constitute a concrete support for understanding the abstract entities that are phonemes. This stance - that thinking about the written code can constitute a fundamental basis for grasping more abstract segmental units - is also corroborated by a transcultural study conducted by Tolchinsky and Teberosky (1998). Working with preschool and second-grade Spanish and Hebrew children, they demonstrated that the ability to segment the oral components of words evolved as the children made progress with alphabetisation.

The idea that the exploration and progression of children's knowledge about written language is reflected in their capacity to analyse speech is also highlighted in Alvarado (1998), Vernon (1998) and Vernon and Ferreiro's (1999) work. For example, to test children with different levels of spelling Alvarado (1998) used an initial-phoneme deletion task applied to words that were both presented verbally and accompanied by a written support. As one might, to some extent, have expected, it was the children at the alphabetic level who achieved the highest success rates - around 50\% in the verbal form and $95 \%$ when the words were accompanied by a written version.

The children at the syllabic-alphabetic and syllabic-with phonetization-levels achieved comparable degrees of success (60\% and 57\%, respectively) when the words were accompanied by a written support, but these rates fell significantly (to $16 \%$ and $8 \%$ ) in the exclusively oral format. A comparison between the children whose spelling was governed by the syllabic hypothesis with and without phonetization suggests that conventional letters play an important role as a factor that facilitates phonemic awareness, inasmuch as in the phonemic test, those who did not yet phonetize only scored $15 \%$ with the written version and $7 \%$ without it. The children at pre-syllabic level failed to score at all in either version of the tests.

Along the same lines, Vernon (1998) showed that children at a less evolved conceptual level provided less analytical answers in a word segmentation test than did their more advanced peers. The same study also confirms that children perform better in segmentation tasks when words are presented in the shape of a written support than they do when the words are only presented verbally. Another research project (Vernon \& Ferreiro, 1999) involving preschool-age children suggests that their responses in a segmentation task display an evolutionary sequence. Initially the children were not able to identify pieces of a word, they then evolved to syllabic analysis, after which they managed an intra-syllabic analysis of the final part of words and finally were able to perform a complete segmental analysis. The type of segmentation response given seemed to depend on the children's familiarity with written language, which was assessed on the basis of their writing.

These three research projects, which demonstrate that phonological skills undergo a gradual evolutional improvement until the point at which the relationships between oral and written language are understood alphabetically, are nonetheless limited by the fact that they focus their analyses on a single phonological task and thus do not take account of the multiple aspects of this particular ability (Stahl \& Murray, 1994; Stanovich, 1992). At the same time, while they are correlational - that is to say, they demonstrate the existence of correspondences between the quality of children's invented spelling and their performance in a phonemic test - they do not manage to provide conclusive evidence of relationships of a causal nature.

Silva and Alves Martins $(2002,2003)$ have conducted various experimental studies in which they compare the effect that training programs intended to lead children to evolve in their ideas about written language had on both the quality of their spelling and their phonological skills. These studies prove that the progresses that pre-syllabic children and syllabic children without phonetization make in their invented spelling have a significant impact on their phonological awareness.

In the light of the fact that the current state of the art indicates that children's invented spelling is a privileged instrument for developing oral analysis skills, and that some authors (Alvarado, 1998; Ouzoulias, 2001; Vernon, 1998; Vernon \& Ferreiro, 1999) even argue that the more complex segmentation and phonemic manipulation skills evolve side-by-side with children's knowledge of writing until they reach the point at which children understand its alphabetic nature, we believe that it is pertinent to take a more in-depth look at this point of view by carrying out experimental intervention studies designed to improve the quality of children's spelling. We feel that this analysis should be undertaken using various means of measuring performance in terms of phonemic awareness, in such a way as to take the heterogeneity and varying degrees of difficulty of the different phonemic tests into account (Adams, 1998; Yopp, 1988).

With the objective of securing a better understanding of the evolution in children's phonemic awareness that results from advances in their knowledge about the nature of the written code, we will thus now present an experimental study that was conducted with children whose spelling was at different levels of evolution. 
We formulated the following research questions:

Would a training program that is designed to make children's invented spelling evolve have an impact on their phonemic awareness? Would that impact differ depending on the level of the children's spelling?

\section{Methods}

\subsection{The experimental design}

This was an experimental study in which children were given a pre-test and a post-test intended to evaluate their invented spelling and their phonemic skills. We established three experimental groups and three control groups based on the nature of the invented spelling that the participants displayed in the pre-test. In between the two tests the experimental groups underwent a training program designed to induce a restructuring of their spelling, while the control groups did exercises involving the categorisation of geometric figures.

The experimental and control group programs began a week after the pre-test and lasted for a fortnight. In order to be sure that any progress that might have been made was of a lasting nature, the post-test was carried out one month after the programs were concluded.

The tests used at the pre- and the post-test moments were the same.

Given the fact that knowledge of letters can serve as an intermediary and an instrument that makes it easier to become aware of phonemic entities (Stahl \& Murray, 1998; Treiman \& Cassar, 1997), we checked how many letters the children were familiar with. We also determined the level of each child's intelligence.

\subsection{Participants}

The participants were 90 middle-class Portuguese children with an average age of 67.94 months and a standard deviation of 4.48 months, a minimum age of 60 months and a maximum age of 80 months. They attended various different kindergartens and had received no formal teaching about reading and writing. Their kindergarten classes did not include any regular classroom activities/instruction in relation to either phonological awareness or invented spelling.

None of the children knew how to read - a fact that was verified in an individual word reading test which had been devised for the Portuguese population (Sim-Sim \& Ramalho, 1993).

The children were divided into three groups on the basis of the nature of their invented spelling in the pre-test. Each group included 30 children.

Group 1 was composed of children whose spelling in the pre-test was pre-syllabic; group 2 was made up of children whose spelling was syllabic without phonetization; while group 3 comprised children who spelt syllabically with phonetization. Each group was then randomly divided into two - an experimental group and a control group.

Eight children did not participate in the whole experiment and have therefore been eliminated from the results. The final composition of the groups was as follows: experimental group $1(N=15)$; control group $1(N=15)$; experimental group $2(N=13)$; control group $2(N=12)$; experimental group $3(N=13)$; control group $3(N=14)$.

Each experimental group matched its respective control group in terms of their age, the number of letters with which the children were familiar and their intelligence.

Table 1 shows the mean scores and standard deviations for the age, the number of letters known by the members of the different groups and for their level of intelligence.

Table 1

Mean scores and standard deviations of the age, the letters known and the levels of intelligence at the pre-test in function of the groups

\begin{tabular}{|c|c|c|c|c|c|c|}
\hline & \multicolumn{2}{|c|}{ Age (months) } & \multicolumn{2}{|c|}{ Letters } & \multicolumn{2}{|c|}{ Intelligence } \\
\hline & $M$ & SD & $M$ & SD & $M$ & SD \\
\hline Exp. G.1 & 70.53 & 5.04 & 7.07 & 6.64 & 18.60 & 2.61 \\
\hline Cont. G.1 & 71.27 & 3.81 & 7.27 & 6.78 & 18.40 & 3.23 \\
\hline Exp. G.2 & 66.23 & 2.77 & 16.62 & 5.28 & 18.08 & 1.98 \\
\hline Cont. G.2 & 66.25 & 3.52 & 13.83 & 6.82 & 18.33 & 1.30 \\
\hline Exp. G.3 & 65.77 & 3.86 & 19.38 & 3.66 & 17.77 & 2.92 \\
\hline Cont. G.3 & 66.64 & 4.29 & 16.57 & 4.31 & 19.14 & 3.23 \\
\hline
\end{tabular}




\section{OL INONOLI Urso \\ OLiNA Rato \\ AROLIN.iA Hipopotamo \\ VZOINAARE Boi

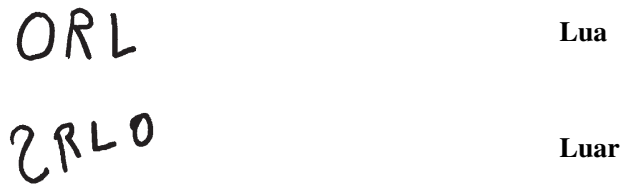

Fig. 1. Example of pre-syllabic spelling.

We performed 3 ANOVA tests using the levels of spelling in the pre-test (pre-syllabic, syllabic, syllabic with phonetization) and the group (experimental or control) as independent variables and the age, the number of letters known or the level of intelligence as dependant variable.

The results of the ANOVA concerning the age show that there are statistically significant differences in function of the levels of spelling $[F(2,76)=13.12 ; p=0.000]$. Post hoc analysis using the Tukey test revealed that there are statistically significant differences between the pre-syllabic children and those of the other two groups. There are no statistically significant effects concerning the group $[F(1,76)=0.38 ; p=0.541]$ and the interaction between the levels of spelling and the group $[F(2,76)=0.09 ; p=0.918]$.

The results of the ANOVA concerning the number of letters known show that there are statistically significant differences in function of the levels of spelling $[F(2,76)=27.41 ; p=0.000]$. Post hoc analysis using the Tukey test revealed that there are statistically significant differences between the pre-syllabic children and those of the other two groups. There are no statistically significant effects concerning the group $[F(1,76)=1.20 ; p=0.162]$ and the interaction between the levels of spelling and the group $[F(2,76)=0.65 ; p=0.526]$.

The results of the ANOVA concerning the level of intelligence show that there are no statistically significant effects of the levels of spelling $[F(2,76)=0.09 ; p=0.911]$, the group $[F(1,76)=0.65 ; p=0.424]$ and the interaction between them $[F(2,76)=0.64 ; p=0.531]$.

\subsection{Tasks and procedure}

\subsubsection{Evaluating the children's invented spelling}

In order to assess the children's invented spelling we asked them to spell their name and then to spell a set of words to the best of their ability. After spelling each word they were asked to read what they had spelled. The verbal utterings that frequently accompanied the act of spelling were recorded.

We dictated 20 words which were organised as follows: words that are of an identical size from a linguistic point of view, but which refer to items that possess different sizes - for example: urso/rato (bear/mouse); words that are of a different size from a linguistic perspective, but which refer to items of a similar size - for example: hipopótamo/boi (hippopotamus/ox); words that belong to the same family, are close in linguistic terms and belong to the 


$\begin{array}{ll}\text { BA } & \text { Urso } \\ N E & \text { Rato } \\ \text { LDAEO } & \text { Hipopótamo } \\ \text { FU } & \text { Boi } \\ E L & \\ \text { RD } & \text { Lua }\end{array}$

Fig. 2. Example of syllabic spelling.

same semantic area - for example: lua/luar (moon/moonlight); singular/plural pairs of words; and words beginning with different vowels and consonants (see Appendix A).

Our classification of the children's responses was inspired by the classification grids drawn up by Ferreiro (1988) and Ferreiro and Teberosky (1982). We employed the following categories: pre-syllabic; syllabic without phonetization; syllabic with phonetization; syllabic-alphabetic/alphabetic.

Pre-syllabic: spellings in which the children made no attempt to establish letter-sound correspondences of any kind, either when they wrote, or when they read their own written productions. They wrote several letters and then read the written string globally. The children spelled words which refer to items that possess different sizes in ways that took account of the properties of the reference items - for example, by using more letters for words that refer to large animals, as urso or boi, and less letters to words that refer to small animals as rato. Fig. 1 illustrates this type of spelling.

Syllabic without phonetization: spellings in which the correspondence between oral and written language was based on syllabic units, as we can see in Fig. 2. These children made a strict one-to-one correspondence between the oral syllables and the letters they wrote. Each syllable was represented by a random letter. They read the words syllabically.

Syllabic with phonetization: spellings in which the correspondence between oral and written language was based on syllabic units, but in which the children phonically analysed part of the spoken words in such a way as to select

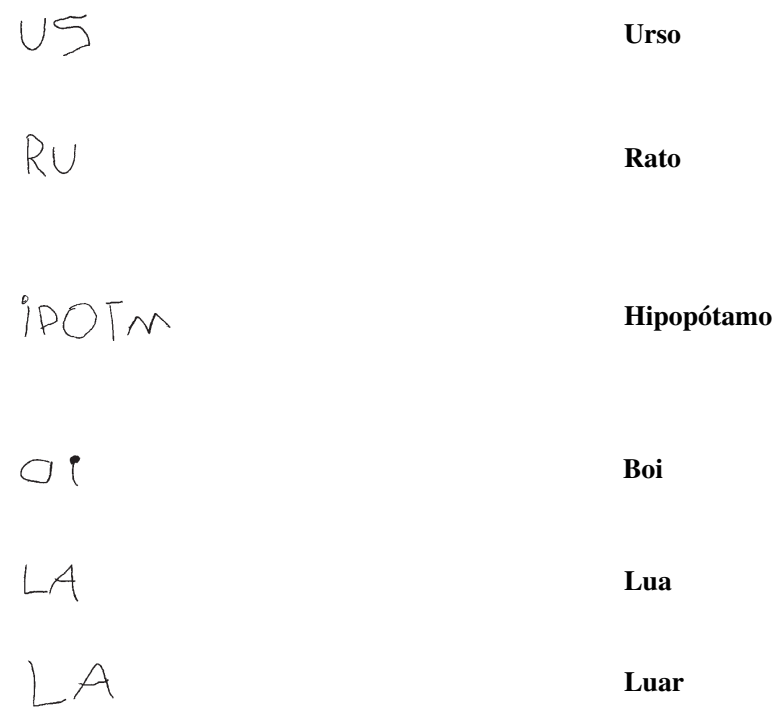

Fig. 3. Example of syllabic spelling with phonetization. 


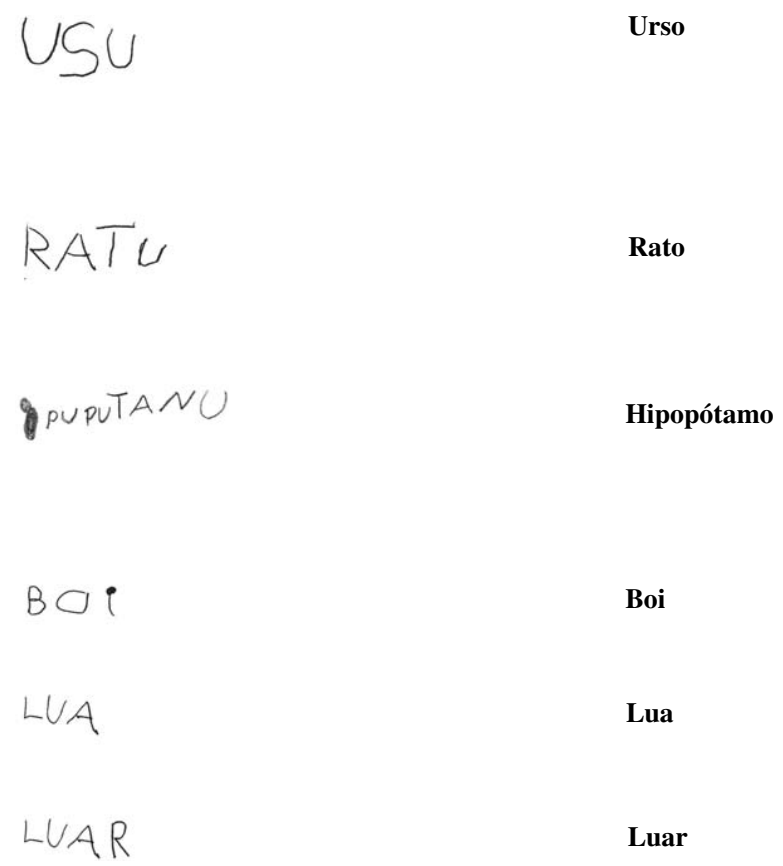

Fig. 4. Example of syllabic-alphabetic/alphabetic spelling.

a pertinent letter to represent the sounds they identified. Fig. 3 illustrates this type of spelling. These children also read the words syllabically.

Syllabic-alphabetic/alphabetic: spellings in which children used pertinent letters to represent all the phonemes in some of the syllables of a word, while continuing to use one letter to denote other syllables in the same word, or spellings in which the phonetic structure of the word was fully learnt and codified, even though not all the applicable orthographic conventions were respected. In both cases the children used pertinent letters to represent sounds. The words were read globally. Fig. 4 illustrates this type of spelling.

We classified each child in a level according to the following procedure: we analysed the way she/he spelled and read each word; we then calculated the number of words that fitted each type of spelling. In order to classify a child in a certain level he/she should write $90 \%$ of the words (18) according to the criteria defined for that level. For instance, there were two children's protocols, whose spelling was syllabic with phonetization for 18 words and syllabic-alphabetic for 2 others; those children were classified as syllabic with phonetization.

This analysis was made by three independent judges. In what concerns the classification of the children in each level of spelling they agreed $100 \%$ in the pre- and the post-tests. If we consider the inter-rater agreement in what concerns the classification word by word using the Kappa statistic we obtained in the pre-test a value of 0.94 and in the post-test a value of 0.92 .

\subsubsection{Evaluating the children's phonemic skills}

In order to evaluate the children's phonemic skills we set them a battery of tests composed of three sub-tests with differing levels of difficulty (so as to address the heterogeneous nature of this particular ability). The battery included one classification test, one deletion test and one segmentation test (see Appendix B).

The initial-phoneme classification test was composed of 14 items preceded by 2 examples. In each item the children were presented with four drawings, each representing an oral word (there were no written words); two of the words in each item began with the same phoneme, whereas the others started with different ones, and the children had to identify the words that began with the same one. When evaluated using Cronbach's alpha, the internal consistency was 0.60 for the pre-test and 0.78 for the post-test.

In the initial-phoneme deletion test the children were asked to pronounce in isolation each of the phones of words that were presented in a figurative form (i.e., each oral word was again represented by a drawing), and to say what 
remained of the word without the initial segment, the deletion of which resulted in something that was not a word in terms of the Portuguese language (e.g., r/i/o; io). The test was made up of 24 items (preceded by two examples). Again using Cronbach's alpha, the internal consistency in this case was 0.94 for the pre-test and 0.97 for the post-test.

In the phonemic segmentation test the children were asked to pronounce in isolation each of the phones in words that were presented to them in figurative form. Each word contained between 2 and 4 phones. The test was made up of 14 items, again preceded by two training items that modelled the division of two words into their phonemic segments. The Cronbach's alpha scores for internal consistency were 0.61 for the pre-test and 0.93 for the post-test.

In all the tests one point was awarded for each correct answer.

\subsubsection{Evaluating the children's knowledge of letters}

In order to determine how many and which letters the children were familiar with, they were given a set of cards bearing the letters of the alphabet in capitals $(\mathrm{K}, \mathrm{W}$, and Y were excluded, inasmuch as they are not formally part of the Portuguese alphabet), which they were asked to name. They were then asked to write down the letters they had recognised. The range of possible points in this test was thus 0 to 23. We considered that a child knew a letter when she/he correctly named it and wrote it down.

\subsubsection{Evaluating the children's intelligence}

The level of the children's intelligence was evaluated using the coloured version of Raven's Progressive Matrices test (Raven, Raven, \& Court, 1998), because it is not very dependent on verbal aspects.

\subsubsection{The training program}

The training program was organised around situations that led the child to think about the rules of spelling from two points of view: his/hers; and that of a hypothetical boy/girl from another school, whose spellings were more advanced. The children of experimental group 1 were presented with syllabic spellings; those in experimental group 2 with syllabic spellings with phonetization; and those in experimental group 3 with syllabic-alphabetic/alphabetic spellings. They were asked to read both of the words carefully, to say which of the two versions was better and to try to justify why they had spelled the word in their way and why the other child had spelled it differently. In addition to these instructions, before they wrote down the words the children from experimental group 1 were asked to say in advance how many letters they were going to have to use. The children from experimental groups 2 and 3 were told to think of the letters that went best with the sounds of each of the words they spelled. Each session involved spelling words that began with the same vowel or consonant. The first syllable of the first word they were asked to spell in each session coincided with a letter name, so as to facilitate the use of that letter - for example, água (water), or pera (pear) in which the syllable "á" or "pe" coincides with the name of the letter A or P (Alves Martins \& Silva, 2001; Mann, 1993).

Besides this, and whenever possible, some of the words partially shared identical sound sequences (e.g. ver (to see), verde (green), vi (I saw), vila (town), vela (candle), vale (valley), viola (guitar), vitelo (male calf), vaso (vase)). As often as we could we also tried to use words in which the graphic-phonetic correspondences were as simple as possible. In all experimental groups the children wrote 10 words beginning with a vowel in the first session, and 8 words, all beginning with the same consonant, in each of the other 7 sessions. All the sessions were individually conducted by us with the child over the course of a fortnight and lasted for approximately $15 \mathrm{~min}$ each. The number of words written by each child was the same.

The program was individualised according to the spelling level of the child. Such individualisation took into account the letters known by each child since the list of the words to be written varied from child to child, depending on the letters with which each was familiar. The main cognitive activities were: predicting the number and the type of letters to be written, comparing his/her own spelling with spellings one level higher, evaluating which one was better, justifying the way of spelling. In this way we created the conditions that would arouse a cognitive conflict in the children and acted in their zone of proximal development, inasmuch as the situation itself led them to think about ways of spelling that were not very distant from their own one.

This program began a week after the pre-test. The children were randomly divided between the two experimenters. 


\subsubsection{The control group program}

We organised a set of exercises with the control group using material of the logical blocks type. The children were asked to classify geometric shapes in accordance with criteria such as identical shape, size or colour. The control group program was equivalent in time to the training one, was individualized and was also conducted by us. The children were again randomly divided between the two experimenters.

\section{Results}

We will begin by giving an account of the evolution of the children's invented spelling. All the members of experimental group 1, whose spelling at the time of the pre-test had been pre-syllabic, were spelling syllabically at the posttest moment; all the children in the respective control group continued to write pre-syllabically. All the children in experimental group 2, who had written syllabically in the pre-test, wrote syllabically with phonetization in the post-test, whereas control group 2's spelling was still not phonetized. All the children in experimental group 3, who had written syllabically with phonetization in the pre-test, produced syllabic-alphabetic and alphabetic spellings at the post-test moment; in the control group, 12 children continued to write syllabically with phonetization, while only two children had begun to produce syllabic-alphabetic spellings.

Moving on to the evolution in the phonemic tests, we will begin with the results achieved in the pre- and post-tests in the three phonemic tests, the descriptive statistics for which are set out in Table 2.

Table 3 shows the correlations between the results obtained in the three phonemic tests at the pre- and post-test moments and between the age, the knowledge of letters, the level of intelligence and the post-test scores in the phonemic tests. As we can see, the correlations between the pre- and post-tests of the three phonemic tests are statistically significant, as well as the correlations between the age (negative ones), the number of letters and the post-test scores. The correlations between the level of intelligence and the post-test results are not statistically significant.

In order to answer our research questions we performed 3 ANCOVA tests using the levels of spelling in the pre-test (pre-syllabic, syllabic, syllabic with phonetization) and the group (experimental or control) as independent variables and the age, the number of letters known and the results achieved in each of the phonemic tests at the pre-test as covariates. The dependent variables were the results achieved in each of the phonemic tests at the post-test.

We introduced the pre-test scores in the phonemic tests and the age and the number of letters known as covariates because they are related to the post-test results as it is shown in Table 3.

It was not necessary to introduce the intelligence level as a covariate because it is not related with the post-test results.

Using the same type of statistical analysis we then determined whether there were any statistically significant interactions between the levels of invented spelling when compared two-by-two (pre-syllabic vs. syllabic; pre-syllabic vs. syllabic with phonetization; syllabic vs. syllabic with phonetization) and the group (experimental and control). In order to control the family wise type I error rate we used a Bonferroni procedure establishing a significance level of 0.05/3.

The results of the ANCOVA concerning the initial-phoneme classification test show that the group $[F(1,73)=69.84 ; p=0.000]$ and the group $\times$ level of spelling interaction $[F(2,73)=3.47 ; p=0.036]$ produced statistically significant effects on the results obtained in the post-test. There were no statistically significant effects concerning the level of spelling $[F(2,73)=2.18 ; p=0.120]$.

Table 2

Mean scores and standard deviations of the results in the pre- and post-tests achieved at the phonemic tests in function of the level of invented spelling and of the group

\begin{tabular}{|c|c|c|c|c|c|c|c|c|c|c|c|c|}
\hline & \multicolumn{4}{|c|}{ Initial-phoneme classification } & \multicolumn{4}{|c|}{ Initial-phoneme deletion } & \multicolumn{4}{|c|}{ Phonemic segmentation } \\
\hline & \multicolumn{2}{|c|}{ Pre-test } & \multicolumn{2}{|c|}{ Post-test } & \multicolumn{2}{|c|}{ Pre-test } & \multicolumn{2}{|c|}{ Post-test } & \multicolumn{2}{|c|}{ Pre-test } & \multicolumn{2}{|c|}{ Post-test } \\
\hline & $M$ & SD & $M$ & SD & $M$ & SD & $M$ & SD & $M$ & SD & $M$ & SD \\
\hline Exp. G.1 & 5.93 & 2.74 & 8.60 & 1.96 & 4.00 & 7.56 & 5.00 & 8.22 & 0.67 & 1.18 & 1.60 & 2.67 \\
\hline Cont. G.1 & 5.20 & 1.52 & 6.00 & 2.51 & 3.87 & 1.60 & 5.13 & 3.09 & 1.07 & 1.44 & 0.67 & 1.23 \\
\hline Exp. G.2 & 6.54 & 2.99 & 11.08 & 2.36 & 6.23 & 5.18 & 15.08 & 7.51 & 0.69 & 1.03 & 7.31 & 3.28 \\
\hline Cont. G.2 & 7.50 & 2.68 & 7.92 & 3.23 & 6.50 & 5.25 & 7.58 & 6.40 & 1.00 & 1.48 & 1.00 & 2.30 \\
\hline Exp. G.3 & 8.23 & 2.59 & 13.00 & 1.15 & 8.69 & 6.12 & 17.62 & 7.46 & 1.62 & 1.61 & 9.62 & 3.12 \\
\hline Cont. G.3 & 7.36 & 2.62 & 7.58 & 2.44 & 9.36 & 5.75 & 13.07 & 7.03 & 1.29 & 1.73 & 2.00 & 2.83 \\
\hline
\end{tabular}


Table 3

Correlations between pre- and post-test scores in the phonemic tests and between the age, the knowledge of letters and the level of intelligence and the post-test scores in the phonemic tests

\begin{tabular}{lllr}
\hline Pre-test & Post-test & & $\begin{array}{l}\text { Phonemic } \\
\text { segmentation }\end{array}$ \\
\cline { 2 - 4 } & $\begin{array}{l}\text { Initial-phoneme } \\
\text { classification }\end{array}$ & $\begin{array}{l}\text { Initial-phoneme } \\
\text { deletion }\end{array}$ & $0.79^{*}$ \\
Initial-phoneme classification & $0.56^{*}$ & & $0.44^{*}$ \\
Initial-phoneme deletion & & $-0.27^{*}$ & $-0.25^{*}$ \\
Phonemic segmentation & $-0.28^{*}$ & $0.43^{*}$ & $0.48^{*}$ \\
Age & $0.45^{*}$ & 0.10 & -0.03 \\
Letters & 0.09 & & \\
Intelligence & & & \\
\hline
\end{tabular}

$* p<0.01$.

We can thus confirm that the training's impact on the initial-phoneme classification test differed depending on the level of the children's spelling.

The pairwise comparisons only revealed statistically significant interactions when we contrasted the pre-syllabic children and the syllabic with phonetization ones $[F(1,50)=8.08 ; p=0.007]$.

Fig. 5 shows the pre- and post-test results on the initial-phoneme classification test in function of the level of invented spelling and the group.

As we can see, the training had less impact on the pre-syllabic children than it did on the syllabic with phonetization ones.

The results of the ANCOVA concerning the initial-phoneme deletion test show that the level of spelling $[F(2,73)=5.61 ; p=0.005]$, the group $[F(1,73)=18.77 ; p=0.000]$ and the group $\times$ level of spelling interaction $[F(2,73)=6.28 ; p=0.003]$ produced statistically significant effects on the results obtained in the post-test.

The pairwise comparisons revealed statistically significant interactions when we contrasted the pre-syllabic children with the syllabic ones $[F(1,48)=14.34 ; p=0.000]$ and the pre-syllabic children and the syllabic with the phonetization ones $[F(1,50)=6.75 ; p=0.012]$.

Fig. 6 shows the pre- and post-test results on the initial-phoneme deletion tests in function of the level of invented spelling and the group.

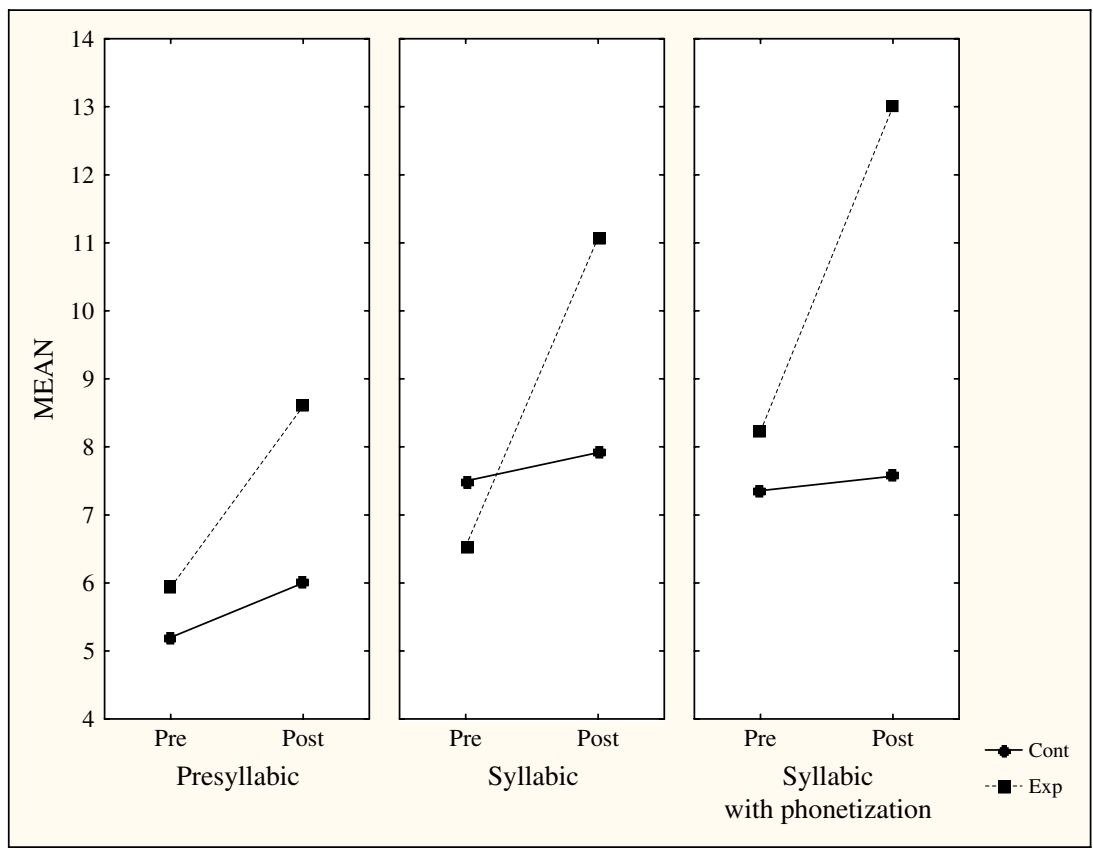

Fig. 5. Pre- and post-tests results achieved at the initial-phoneme classification test in function of the level of invented spelling and of the group. 


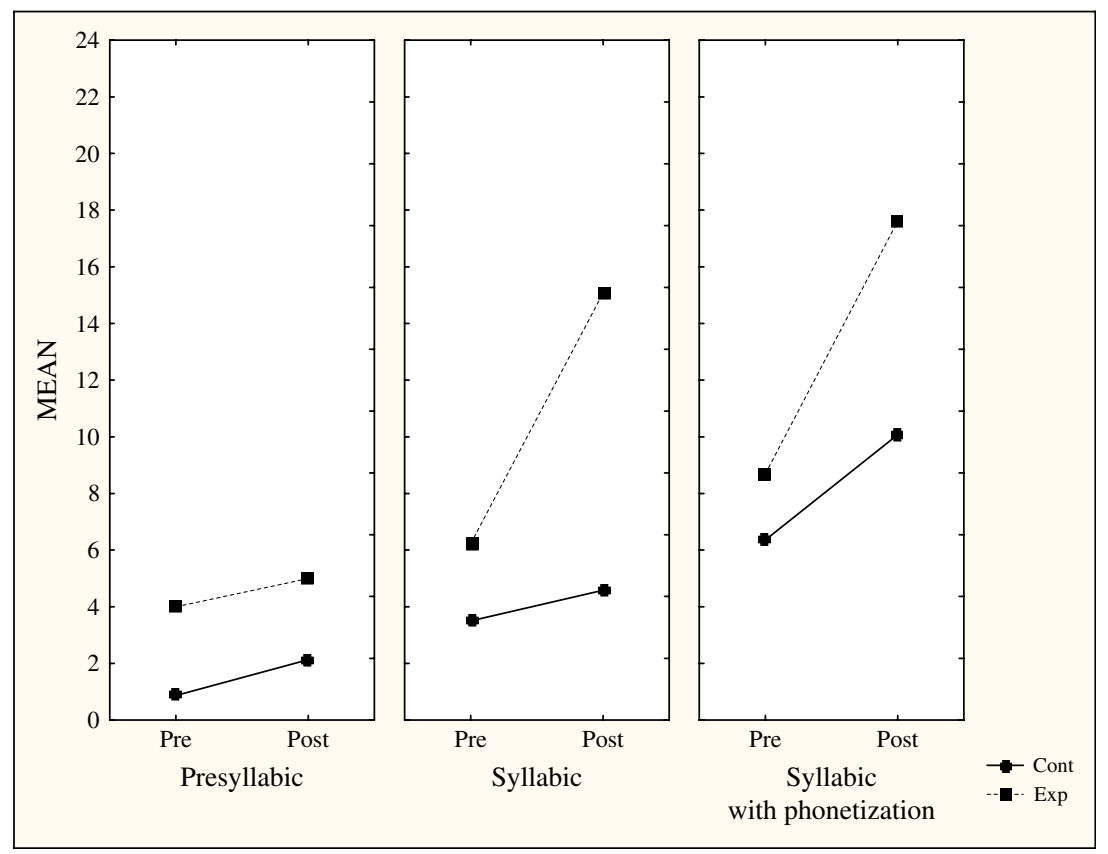

Fig. 6. Pre- and post-test results achieved at the initial-phoneme deletion test in function of the level of invented spelling and of the group.

We can see that the training program had less impact on the pre-syllabic children than on the children who wrote syllabically, with and without phonetization.

The results of the ANCOVA concerning the phonemic segmentation test show that the level of spelling $[F(2,73)=13.10 ; p=0.000]$, the group $[F(1,73)=120.50 ; p=0.000]$ and the group $\times$ level of spelling interaction $[F(2,73)=16.49 ; p=0.000]$ produced statistically significant effects on the results obtained in the post-test.

The pairwise comparisons revealed statistically significant interactions when we contrasted the pre-syllabic children and the syllabic ones $[F(1,48)=29.53 ; p=0.000]$ and the pre-syllabic children and the syllabic with the phonetization ones $[F(1,50)=26.41 ; p=0.000]$.

Fig. 7 shows the pre- and post-test results on the phonemic segmentation test in function of the level of invented spelling and the group.

As we can see, the training program had less impact on the pre-syllabic children than on the children from the other two groups.

In summary, we can see that in the case of the initial-phoneme classification test the interaction effects were due to the differences between children who are pre-syllabic and children who are syllabic with phonetization, while in the other two phonemic tests they were derived from the differences between pre-syllabic children and children at the other two levels of invented spelling.

In order to analyse the differences between experimental and control conditions for each group we performed 9 ANCOVA tests using the group as independent variable, the results achieved in each of the phonemic tests at the pre-test as covariates and the results achieved in each of the phonemic tests at the post-test as dependant variables.

The results of the ANCOVA tests concerning the initial-phoneme classification test, show that the training produced statistically significant differences in the post-test results for the pre-syllabic children $[F(1,27)=9.07$; $p=0.006]$, for the syllabic children $[F(1,22)=17.16 ; p=0.000]$ and for the syllabic with phonetization ones $[F(1,24)=88.89 ; p=0.000]$.

The results concerning the initial-phoneme deletion test show that there are statistically significant differences between the experimental and the control group for the syllabic children $[F(1,22)=14.19 ; p=0.001]$ and the syllabic with phonetization ones $[F(1,24)=7.74 ; p=0.010]$. There are no statistically significant differences between the presyllabic experimental and control groups.

The results concerning the phonemic segmentation test show that there are statistically significant differences between the experimental and the control group for the pre-syllabic children $[F(1,27)=4.85 ; p=0.036]$, for the 


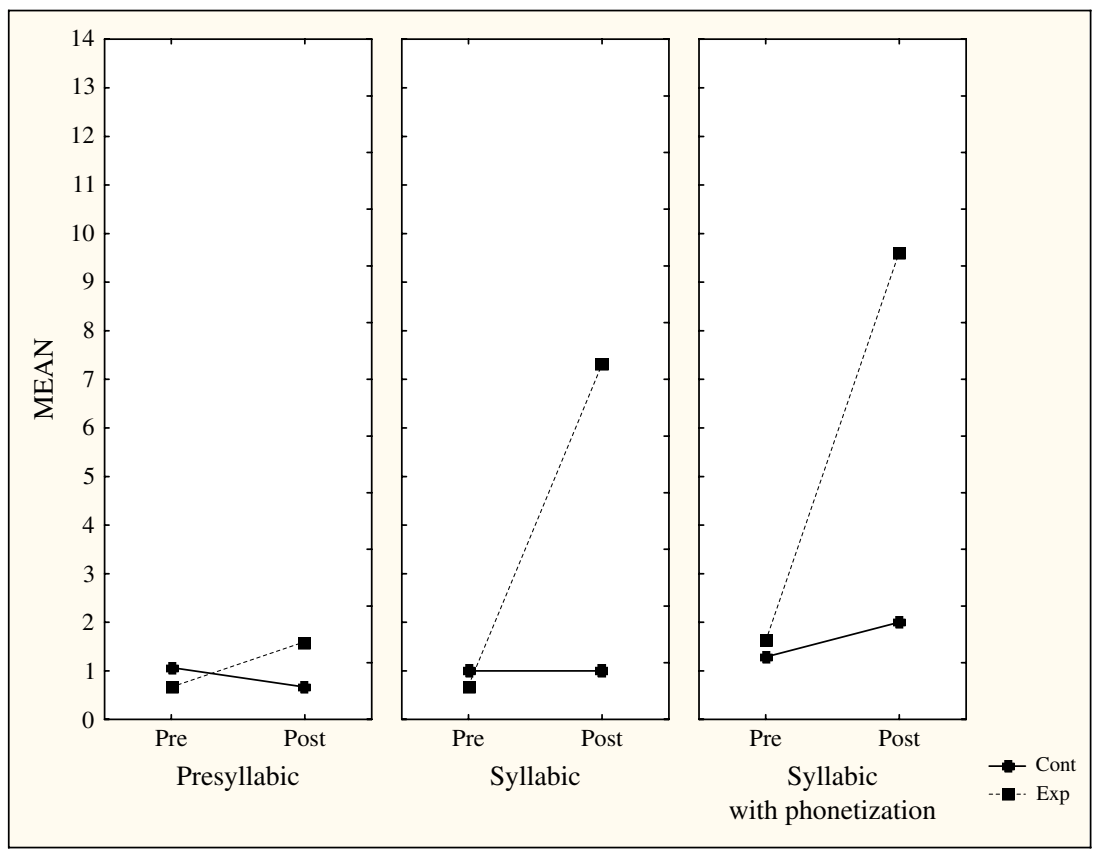

Fig. 7. Pre- and post-test results achieved at the phonemic segmentation test in function of the level of invented spelling and of the group.

syllabic children $[F(1,22)=106.27 ; p=0.000]$ and for the syllabic with phonetization ones $[F(1,24)=55.03$; $p=0.000]$.

\section{Discussion}

The results we obtained indicate that the training program led the children to improve their performance in phonemic awareness tasks. All the experimental conditions except one (pre-syllabic children results in the initial-phoneme deletion test) produced statistically significant effects in the post-test results.

Our data thus support the idea that involvement in writing situations prior to formal education is a factor in the development of phonemic awareness and that this is true from quite elementary forms of spelling onwards. This stance is in agreement with the positions taken by Adams (1998), Alvarado (1998), Treiman (1998), Vernon (1998) and Vernon and Ferreiro (1999), who believe that children's invented spelling is an important instrument for the development of awareness of the oral segments of words. They also support the point of view taken by Ferreiro (2002), when she says that awareness of phonemes "results from a new level of reorganisation of the units in speech, which is made possible by writing" (p. 161). Our data operationalize this perspective within the framework of a precise causal relationship and over the course of an evolutionary path that goes all the way from relatively elementary forms of spelling to syllabic-alphabetic and alphabetic spellings. Our study reinforces the idea that there is a complex interaction between the processes involved in becoming aware of the oral units in speech and the understanding of the way in which the written code works that children achieve thanks to their invented spelling activities.

At the same time our results show that there are differences in the scores of phonological awareness tasks which depend on the nature of the conceptual discoveries about the relationships between oral and written language that a training program induces in the children. This differential impact becomes evident when we analyse the progress that the children made in the three phonemic tests in the light of the nature of the demands made by each one.

In the initial-phoneme classification test - a test that is considered to be an indicator of phonemic awareness (Stahl \& Murray, 1998) - we can see that all the experimental groups made significant progress compared to their respective control groups. The post-test results obtained by experimental group 1 suggest that the simple fact that children are beginning to establish systematic relationships between letters and syllables favours a gradual awareness that different words possess common sounds; it seems that the mobilisation of letters that are activated as a support which represents a segment of the spoken word, introduces a metalinguistic word-analysis practise that can lead to improvements in the 
process of becoming aware of phonemic entities, albeit in a rudimentary manner. However, the facilitating role that letters play as a support in the process of becoming aware of phonemic entities goes significantly deeper from the moment at which children begin to mobilise conventional letters to represent the sounds in words that go beyond syllables - a conclusion which may be drawn from the fact that the scores which experimental group 3 obtained in this test were clearly superior to those made by experimental group 1. These data corroborate Stahl and Murray's (1998) proposition that the process whereby children search for the best letters with which to match the sounds of words fosters an analytical attitude towards the spoken word, in which the letters that are chosen serve as tangible intermediaries for an awareness of phonemic entities.

In the initial-phoneme deletion test the relative similarity of the results achieved by experimental groups 2 and 3 also shows that performance in this task in cases in which the phoneme that is to be deleted coincides with the onset of the syllable (as in the test we used) is facilitated when children become aware of phonemic entities (Treiman, 1992). However, unlike in the initial-phoneme classification task, in this test experimental group 1 had poor results in the post-test and did not achieve statistically significant progresses if compared with control group. This result is probably explained by a combination of the complexity of the test, which requires the children to retain a segmental unit in their working memory while they perform the rest of the operations (Yopp, 1988), and the fact that these children's phonemic awareness was still quite limited. It is important to notice that this is one of the most difficult phonemic tasks and most of the times children only have success on it after being competent readers (Perfetti et al., 1987).

In the phonemic segmentation test the differences between the results obtained by experimental groups 2 and 3 in the post-test and those obtained by experimental group 1 confirm Ouzoulias' (2001) view that the preschool-age children who achieve the best results in phonetic segmentation tasks are those who not only understand that written language codes oral language, but also use conventional letters, albeit still at a syllabic level.

When it come to their implications for education, our data support the hypothesis that in order to prevent difficulties with learning to read, phonological training programs could be replaced, or at least complemented, by activities that stimulate children to produce invented spelling and to think about their written output. In this respect invented writing appears to be a way of organising and expanding children's abilities to analyse speech. This position is close to the stances taken by Stahl and Murray (1998) and Vernon and Ferreiro (1999). Stahl and Murray question the usefulness of the emphasis that is placed on training aimed at phonological prerequisites, when applied to children who are not very familiar with written language. They consider that better use would be made of the time that is invested in phonological training programs for such children if it were employed "in reading and writing situations in which the child is led to see writing as a way of noting words, clarify the notion of words, understand the phonographic principle at syllable level, memorise an initial written lexicon and familiarise him/herself with letters of the alphabet" (Stahl and Murray, 1998, p. 121).

Compared to phonological awareness programs, the advantage of activities involving invented spelling and the exploration of written language in a variety of formats derives from the fact that they facilitate the promotion of phonological abilities and simultaneously have an effect on the acquisition of a set of types of know-how to do with written language - particularly the uses and functions of writing, the conventions that govern it and the relationship between the various kinds of writing supports and the structure of the written texts that are associated with them. As Vernon and Ferreiro (1999) say, "Participation in language games may allow children to learn about rhymes and other linguistic phenomena, but the fact remains that perhaps the only everyday activities that require segmental phonological awareness are writing and reading. Writing seems to be both an end in itself and an instrument for achieving a specific kind of language knowledge" (p. 411).

At the same time, it also seems to us important to draw attention to the principles that guided our spelling training program. We provided the children with incentives to take an active role in building up their own knowledge, thereby leading them to make discoveries and to mobilise their knowledge and skills when they spelled; we created conflicts based on comparisons between two ways of spelling; and we acted in their zone of proximal development. The effectiveness of these guidelines - which is indicated by the way in which the children's invented spelling evolved - suggests that it would be useful to intentionally mobilise them in educational contexts. To put it another way, it seems to us important to transpose these educational guidelines into real classroom contexts and to mobilise them in a variety of activities that encompass the exploration and production of written language. At the same time, the implementation of these principles in pedagogical contexts must take account of the knowledge and concepts about writing that the children concerned already possess, in such a way as to maximise their ability to think about their own writing. 
The results we obtained in this study give rise to interesting possibilities in terms of new research. It would be interesting to replicate this research and evaluate the contribution of the main features of the program, predicting, comparing, evaluating and justifying, to the effectiveness of the results obtained. Bearing in mind that familiarity with some letters is essential to an understanding of the alphabetic principle, it would also be useful to replicate this research by creating groups with identical levels of invented spelling, but with contrasts in terms of the number of letters that the children know. It would also be interesting to undertake training programs with children whose invented spelling is at an identical level and who are familiar with the same number of letters, in which some of them would be confronted with spelling at a conceptual level close to their own, while others would be faced with spelling that was clearly more evolved. The purpose of this would be to understand whether the programs had different impacts on the quality of the children's invented spelling and on their phonemic awareness.

Knowledge of the path that children take up until the point at which they understand the alphabetic principle and of the interaction between the various skills required for them to do so is a keystone in the prevention of difficulties in learning to read. The study we have presented herein provides evidence of the importance of invented spelling activities as a means of enhancing the development of phonemic awareness and an understanding of the logic behind the alphabet. In this respect it seems to us pertinent to conclude that stimulating children to write and to think about their own writing facilitates the alphabetisation process.

\section{Appendix A. Words used to evaluate the children's invented spelling}

Pairs of words that are of an identical size from a syllabic point of view, but which refer to items that possess different sizes

urso/rato (bear/mouse); cavalo/formiga (horse/ant)

Pairs of words that are of a different size from a syllabic perspective, but which refer to items of a similar size

hipopótamo/boi (hippopotamus/ox); leopardo/tigre (leopard/tiger)

Pairs of words that belong to the same family, are close in linguistic terms and belong to the same semantic area

lua/luar (moon/moonlight)

Singular/plural pairs of words

gato/gatos (cat/cats)

Words beginning with different vowels and consonants

asa (wing); dente (tooth); elefante (elephant); mosca (fly); ovelha (sheep); pulga (flee); sapo (toad); vaca (cow).

\section{Appendix B. Battery of phonological tests}

Initial-phoneme classification test

Cards with drawings representing:

Examples:

colher/chave/chuva/bola (spoon/key/rain/ball)

jóia/nó/jipe/pá (jewel/knot/jeep/shovel) 
Items:

alce/urso/arca/ovo (moose/bear/arch/egg)

orelha/alface/árvore/igreja (ear/lettuce/tree/church)

raposa/regador/viola/boneca (fox/watering-pot/guitar/doll)

mala/peixe/chucha/mota (bag/fish/(baby's) dummy/motorcycle)

sumo/gola/leite/gato (juice/coller/milk/cat)

buzina/cegonha/vassoura/veado (horn/stork/broom/deer)

serra/copo/cama/lupa (saw/glass/bed/magnifying glass)

fivela/telhado/janela/fogueira (buckle/roof/window/bonfire)

boca/tigre/selo/tacho (mouth/tiger/stamp/pot)

pato/pêra/milho/chuva (duck/pear/corn/rain)

tijolo/bolacha/seringa/banana (brick/biscuit/syringe/banana)

cebola/toalha/gaveta/cigarro (oignon/towel/drawer/cigarette)

lata/luva/roda/fita (can/glove/wheel/ribbon)

desenho/camisa/dominó/novelo (drawing/shirt/domino/ball of wool).

\section{Initial-phoneme deletion test}

Cards with drawings representing:

Examples:

noz (nut); bóia (life buoy)

Items:

rio (river); rosa (rose); mel (honey); mola (clothespin); gás (gas); galo (cock); vale (valley); vila (village); cão (dog); capa (overcoat); fio (thread); fava (broad bean); torre (tower); telha (tile); pão (bread); pipa (barrel); boi (ox); bolo (cake); sal (sault); sumo (juice); lua (moon); lula (squid); dente (tooth); dedo (finger).

\section{Phonemic segmentation test}

Cards with drawings representing:

Examples:

chá (tea); osso (bone)

Items:

asa (wing); avô (grandfather); rua (street); mar (sea); gorro (beret); via (way); carro (car); figo (fig); taça (cup); pá (shovel); bule (teapot); sol (sun); lã (wool); dia (day).

\section{References}

Adams, M. (1998). Beginning to read: Thinking and learning about print. Cambridge, MA: MIT Press.

Alvarado, M. (1998). Consciencia fonológica y escritura en ninos preescolares: la posibilidad de omitir el primer segmento. Lectura y Vida, 3 , 42-50.

Alves Martins, M. (1993). Évolution des conceptualisations d'un groupe d'enfants d'âge pré-scolaire sur l'écriture portugaise. Études de Linguistique Appliquée, 91, 60-69.

Alves Martins, M., \& Silva, C. (2001). Letter names, phonological awareness and the phonetization of writing. European Journal of Psychology of Education, 16, 605-617.

Besse, J.-M. (1996). An approach to writing in kindergaten. In C. Pontecorvo, M. Orsolini, B. Burge, \& L. Resnick (Eds.), Children's early text construction (pp. 127-144). New Jersey: Lawrence Erlbaum.

Bus, A., Marinus, H., \& Ijzendoorn, V. (1999). Phonological awareness and early reading: a meta-analysis of experimental training studies. Journal of Educational Psychology, 91, 403-414. 
Ferreiro, E. (1984). The underlying logic of literacy development. In H. Goelman, A. Oberg, \& F. Smith (Eds.), Awakening to literacy (pp. 154173). Portsmouth, London: Heinemann Educational Books.

Ferreiro, E. (1988). L'écriture avant la lettre. In H. Sinclair (Ed.), La prodution des notations chez le jeune enfant (pp. 18-69). Paris: Presses Universitaires de France.

Ferreiro, E. (2002). Escritura y oralidad: Unidades, niveles de análisis y consciencia metalinguistica. In E. Ferreiro (Ed.), Relaciones de (in)dependencia entr oralidad y escritura. Barcelona: Geddisa editorial.

Ferreiro, E., \& Teberosky, A. (1982). Literacy before schooling. Exter, NH: Heineman Education.

Goswami, U., \& Bryant, P. (1990). Phonological skills and learning to read. Hove: Lawrence Erlbaum.

Liberman, I. Y., \& Shankweiler, D. (1989). Phonologie et apprentissage de la lecture: Une introduction. In L. Rieben, \& C. Perfetti (Eds.), L'apprentti lecteur. Recherches empiriques et implications pédagógiques (pp. 23-42). Neuchâtel-Paris: Delachaux et Niestlé.

Mann, V. (1984). Reading skill and language skill. Developmental Review, 6, 1-15.

Mann, V. (1993). Phoneme awareness and future reading ability. Journal of Learning Disabilities, 26, 259-269.

Morais, J., Cary, L., Alegria, J., \& Bertelson, P. (1979). Does awareness of speech as a sequence of phonemes arises spontaneously? Cognition, 7 , $323-331$.

Ouzoulias, A. (2001). L'emergence de la conscience phonémique: apprentissage sensoriel ou développment conceptuel. In G. Chauveau (Ed.), Comprendre l' enfant lecteur (pp. 101-127). Paris: Retz.

Perfetti, C., Beck, I., Bell, L., \& Hugues, C. (1987). Phonemic knowledge and learning to read are reciprocal: a longitudinal study of first grade children. Merrill Palmer Quarterly, 33, 283-319.

Pontecorvo, C., \& Orsolini, M. (1996). Writing and written language in children's development. In C. Pontecorvo, M. Orsolini, B. Burge, \& L. Resnick (Eds.), Children's early text construction (pp. 3-23). Hillsdale, NJ: Lawrence Erlbaum Associates Publishers.

Raven, J., Raven, J. C., \& Court, J. H. (1998). Manual for Raven's progressive matrices and vocabulary scale. Section I. General overview. Oxford: Oxford Psychologists Press.

Read, C. (1986). Children's creative spellings. London: Routleddge \& Kegan Paul.

Richgels, D. (1995). Invented spelling ability and printed word learning in kindergarten. Reading Research Quarterly, 30, 96-109.

Silva, C., \& Alves Martins, M. (2002). Phonological skills and writing of pre-syllabic children. Reading Research Quarterly, 37, 466-483.

Silva, C., \& Alves Martins, M. (2003). Relations between children's invented spelling and the development of phonological awareness. Educational Psychology, 23, 3-16.

Sim-Sim, I., \& Ramalho, G. (1993). Como lêem as nossas crianças. Caracterização do nível de literacia da população escolar portuguesa. Lisboa: Ministério da Educação, Gabinete de Estudos e Planeamento.

Stahl, S., \& Murray, B. (1994). Defining phonological awareness and its relationship with early reading. Journal of Educational Psychology, 86, 221-234.

Stahl, S., \& Murray, B. (1998). Issues involved in defining phonological awareness and its relation to early reading. In J. L. Metsala, \& L. C. Ehri (Eds.), Word recognition in beginning literacy (pp. 65-85). London: Lawrence Erlbaum Associates Publishers.

Stanovich, K. (1992). Speculations on the causes and consequences of individual diferences in early reading acquisiton. In P. Gough, L. Ehri, \& R. Treiman (Eds.), Reading acquisition (pp. 307-347). New Jersey: Lawrence Erlbaum.

Sulzby, E. (1989). Assessment of emergent writing and children's language while writing. In L. Morrow, \& J. Smith (Eds.), Writing in real time: Modelling production processes (pp. 83-109). New York: Longman.

Tolchinsky, L. L. (1995). Desenvolvimento da alfabetização e suas implicações pedagógicas: Evidências do sistema hebraico de escrita. In Y. Goodman (Ed.), Como as crianças constroem a leitura e a escrita (pp. 36-53). Porto Alegre: Artes Médicas.

Tolchinsky, L. L., \& Teberosky, A. (1998). The development of word segmentation and writing in two scripts. Cognitive Development, 13, 1-24.

Treiman, R. (1992). The role of intrasyllabic units in learning to read and spell. In P. Gough, L. Ehri, \& R. Treiman (Eds.), Reading acquisition. New Jersey: Lawrence Erlbaum.

Treiman, R. (1998). Why spelling? The benefits of incorporating spelling into beginning to reading instruction. In J. L. Metsala, \& L. C. Ehri (Eds.), Word recognition in beginning literacy (pp. 289-313). London: Lawrence Erlbaum Associates Publishers.

Treiman, R., \& Cassar, M. (1997). L'acquisition de l'orthographe en anglais. In L. Rieben, M. Fayol, \& C. Perfetti (Eds.), Des orthographes et leur acquisition (pp. 79-99). Paris: Delachaux et Niestlé.

Treiman, R., Tincoff, R., \& Richmond-Welty, E. (1997). Beyond zebra: preschoolers' knowledge about letters. Applied Psycholinguistics, 18, 391-409.

Troia, G. (1999). Phonological awareness intervention research: a critical review of experimental methodology. Reading Research Quarterly, 34, 28-52.

Vernon, S. (1998). Escritura Y consciencia fonológica en niños hispano-parlantes. Infancia y Aprendizaje, 81, $105-120$.

Vernon, S., \& Ferreiro, E. (1999). Writing development: a neglegted variable in the consideration of phonological awareness. Harvard Educational Revue, 69, 395-415.

Wagner, R. K., \& Torgesen, J. (1987). The nature of phonological processing and its causal role in the acquisition of reading skills. Psychological Bulletin, 101, 192-212.

Yopp, H. K. (1988). The validity and reliability of phonemic awareness test. Reading Research Quarterly, 23, 159-177. 